\title{
Biases In Managerial Decision Making: Overconfidence, Status Quo, Anchoring, Hindsight, Availability
}

\author{
SELIM AREN* and HATICE NAYMAN HAMAMCI \\ ${ }^{1}$ Department of Accounting and Finance, Yildiz Technical University, İstanbul, Turkey.
}

\begin{abstract}
Decision-making processes occur with the interaction of some cognitive and psychological variables. Neoclassical theories deal with rational reactions in these processes. However, in an environment where there is no information or where there is uncertainty instead of risk, decisions cannot be made rationally as the mind indicates. In this direction, firm managers have to make many decisions under uncertainty. For this reason, managers resort to various simple and useful shortcuts called bias for different reasons. In this study, it was aimed to reveal the effects of behavioral biases on management decisions. In this context, five biases in the behavioral finance literature, namely overconfidence, status quo, anchoring, hindsight and availability, were evaluated with theoretical and empirical studies and their effects on managerial decisions were discussed. It was seen that raising awareness of these biases in terms of managers provides benefits such as realistic evaluation of themselves, giving more realistic weights to events when making decisions, reaching rational judgments more easily and being open to innovations. In addition, this awareness, when combined with the emotional competencies of managers, helps them make successful decisions.
\end{abstract}

\section{Introduction}

Neoclassical theories of economics deal with rational reactions to economic motives. However, there are irrational reactions to economic motives in real life, as well as non-economic motives and rational or irrational reactions to them. The source of these reactions may be external factors as well as conscious or unconscious stimuli coming from within. Keynes's animal spirits theory indicates this point and addresses the impact of conscious and unconscious stimuli from human nature on decisions (Akerlof and Shiller, 2009). Keynes states that there is little or no information to estimate the ten-year return of a building (Akerlof and Shiller, 2009). In an environment where there is no information or there

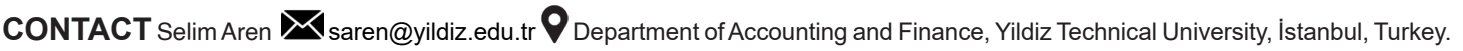
(c) (i)

(C) 2021 The Author(s). Published by Enviro Research Publishers.

This is an $\partial$ Open Access article licensed under a Creative Commons license: Attribution 4.0 International (CC-BY).

Doi: http://dx.doi.org/10.12944/JBSFM.03.01-02.03 
is uncertainty instead of risk, decisions cannot be taken rationally, as the mind indicates.

Business executives also have to make many decisions under uncertainty (Aren, 2019a). In this case, the first thing they need to do is to separate the data and the noises that look like data. Then they need to generate information from the data. Some of the information produced indicates positive effects for the business and some indicatesnegative effects. At this stage, these should be weighted and theireffects on the business should be calculated. However, this requires knowledge. But every manager does not have the same competence. Some of the managers use various simple and useful shortcuts due to their low analysisskills and knowledge, while others apply thembecause of their high knowledge, skills and abilities (Bratianu et al., 2020)

In this context, Simon (1972) states that decisionmakers in the business world benefit from decisionmaking processes that will help them and that their bounded capabilities are critical in the success of the decision process. Tversky and Kahneman (1979) conceptualized that in the context of prospect theory, decision-makers could not make rational decisions at risk and that their decisions were influenced by various psychological biases. Bias is the prejudicial judgment of a situation or thing (human or object). It is inherently personal; however, it contains systematic errors due to the judgment of many people moving away from the rational choice in the same direction. Aren (2019a) expresses biases as shortcuts that people use due to the nature of their daily lives. Shortcuts are practical and help make quick decisions. A shortcut doesn't have to be absolutely erroneous. It can also be seen in experienced people and experts (Tversky and Kahneman 1974), and combined with experience, it is very useful for establishing judgment on complex and difficult issues.

The mind is not the only determinant of judgment; emotions are also important. In fact, neither the mind nor the emotions point to the right decision singly. Rose (2005) states that mental processes work with the interaction of affective and cognitive features and based on meanings. Signification takes place through the interaction of language, experience, social and natural environment (Rose, 2005).
For this reason, the way in which each individual perceives and makes sense of external stimuli is unique. This culture is influenced by society and language, but individual differences can be seen as it is shaped by experience. Humans are social entities. Thus, social norms besides their knowledge also affect their decisions. Norms are social rules that dictate how individuals should behave (Akerlof and Kranton, 2010). These rules are sometimes obvious and sometimes hidden. However, they have been adapted and internalized by society. Norms, besides influencing decisions, also tell how individuals will behave, how they will be, or even what should be loved or not. They exist in and even act as a determinant of social life. Asch's works show very well the group dynamics in individuals' decisions. Norms are internalized over time with the approval or rejection of the group. People follow the norms because they think that they will be punished when they don't.

Akerlof and Kranton (2010) incorporate norms into economic theory in their book Identity Economics. In order for identity to be formed, people must first be defined as buyers and sellers. Then the norms that apply to these categories form and individuals associate their gains and losses from their decisions with these norms (Akerlof and Kranton, 2010). Also, Akerlof and Kranton (2010) state that norms affect behaviors. Therefore, norms sometimes act as information in the markets. What is evaluated as gain and what is loss is shaped with norms. In their anchoring effect, the power of norms is clearly seen. Judgments change when the purchase price, the highest price, or a completely different value is the anchor. These values are essential information. Information plays a role in the decisions that managers take in their professional lives. However, linking decisions only to the possessed knowledge and even to the ability to analyze this information provides a very limited overview. Cristofaro (2017a) points out the importance of personality traits and cognitive styles in increasing decision quality. The effect of the manager's personality traits, value judgments and norms regarding the company or professional group to which s/he belongs is undeniable. All of these features cause shortcuts in managers that they are unaware of. As stated above, theyhelp to make successful decisions when its reasons are known and combined with emotional competence. However, in the theoretical 
and empirical studies conducted in recent years, how these concepts affect management research has not been comprehensively discussed (Cristofaro, 2017b). In the study, it is aimed to discuss the effects of behavioral biases on managerial decisions and to raise awareness in managers in this direction. In this context, overconfidence, status quo, anchoring, hindsight and availability biases of managers were evaluated in order to help to raise this awareness. In each subtitle, the conceptual evaluation of the related bias, its psychological bases, its relations with other psychological and demographic variables, and its effect on risk perception was evaluated. In the discussion and implications section, the general evaluation of the relevant section was made and its contribution was emphasized.

\section{Overconfidence}

Aren and Canikli (2018) define overconfidence as the overvaluation of an individual's knowledge and ability. In other words, overconfidence is the difference between the value that the individual attributes to their knowledge and ability, and the real situation. The higher this difference is, the more overconfidence the individual is considered to have. For this reason, overconfidence can also be considered as the difference between confidence and accuracy (Schaefer et al., 2004; Michailova et al., 2017). Mota et al. (2015) admit it as a mistake that to have overconfidence by ignoring the uncertainty that is inherent in the markets. The main factor causing this error is the confusion of individuals with the amount of information they have and the quality of the information. Nowadays, the real problem is not the scarcity of information, but its multitude. Many managers believe that if they have a lot of information, they can make better decisions. However, with the increase of information channels, "information cloning" is in question. The information from a single source can come from many different channels, and the manager at the decision stage reaches the judiciary believing that $\mathrm{s} /$ he verifies the information and it is good quality. Another problem created by the multitude of information is the difficulty of evaluation. It is accepted that the human brain cannot evaluate more than eight pieces of information at the same time. In this case, the manager distinguishes the information as significant and insignificant based on his/her knowledge and experience, and attributes importance to the information s/he considers important. Aren (2019b) states that overconfidence is activated at this stage and the evaluation is made within this framework. Similarly, Peon et al. (2016) state that the existing uncertainty that exists may cause overconfidence in the individual's evaluations. Overconfidence does not only lead to an erroneous decision (Aren, 2019b), it is sometimes the source of the right decision (Johnson and Fowler, 2011). For this reason, it is said that successful people have overconfidence but overconfidence is not the determinant of success. Supporting this, Moore and Schatz (2017) state that overconfidence is not sole and unitary. Aren (2019b) emphasizes the necessity of evaluation under three headings:

\section{- Overestimation/Miscalibration \\ - Better than Average/Overplacement \\ - Overprecision}

The first type of overconfidence, overestimation or miscalibration; is the excessive or incorrect weighting of the knowledge that an individual has and their analytical skills (Chuang and Lee, 2006; Johnson and Fowler, 2011; Lambert et al., 2012; Fellner and Krugel, 2012; Mota et al., 2015). It is one of the biases that successful people can have. Successful managers show a tendency to overestimate their analytics capabilities when they make many successful decisions in the past. Their past success gives them confidence; however, an important point that they miss is that uncertainty dominates the markets which have no memory. While the correctness of a decision taken in the case of uncertainty is sometimes related to the ability of the decision-maker, sometimes it may depend on variables that cannot be controlled and can be defined as luck. In addition, past successful decisions are determinants of future successful decisions, but they are not the only determinants. However, human psychology is more prone to link successful decisions to their abilities. For this reason, successes, as stated above, create and strengthen overconfidence.

On the other hand, there may be an overestimation or miscalibration of the information possessed. Fellner and Krugel (2012) mention three kinds of information sources:public information, new information produced by carrying past public information to the future with projection and 
private information. While decision makers give low weight to public information, they give high weight to private information (Aren, 2019b). For managers, such behavior may result from seeing himself/herself superior or may be due to anxiety of appearing superior in the eyes of others. Especially professional managers are responsible to give an account to the board and partners. In order for his/her job and prestige to continue, s/he has to show that s/ he has superior qualities than other managers. This obligation may encourage his/her to overestimate his/her knowledge and ability.

The second type of overconfidence is better than average. In this type, one sees his/her knowledge and ability higher than others, rather than exaggerating. The individual does not consider himself/herself very superior but believes that $s /$ he is better than the average (Benoit and Dubra, 2011; Fellner and Kruegel, 2012; Lambert et al., 2012; Broihanne et al., 2014; Costa et al., 2017; Czerwonka, 2017). This is a much more common pattern of behavior than the first (Moore and Schatz 2017). Svenson (1981) reported very interesting findings regarding this subject in his study. All candidates who took the driving license exam in the USA and Sweden were asked to evaluate their driving abilities. $93 \%$ of the candidates in the USA and $69 \%$ of the candidates in Sweden evaluated themselves better than the average. The phenomenon underlying this result is considered to be "better than average". Similarly, the environment of professional managers is not different. CEOs, working in very competitive conditions, must constantly be superior to their peers. This is not a situation which can be easily achieved. For this reason, in an article published in Harvard Law School Forum on Corporate Governance in 2018, it is stated that the CEO turnover fell to 5 years. Todd (2019) also stated that based on Challenger Gray \& Christmas data, 1,160 CEOs quit work in the first nine months of 2019 in the USA. In an environment of such intense competition, even if managers do not claim that they have superior characteristics, they have to express to be better than average to the people they are responsible for. This causes them to be exposed to this type of bias in the process.

The third type of overconfidence is overprecision. Overprecision is a false belief that the individual knows more than s/he knows (Moore and Schatz, 2017). The critical point here is the belief in judgment
(Fellner and Kruegel, 2012; Czerwonka, 2017). First, people are asked to estimate the uncertain future, and then to predict the probability of this prediction being correct. As a result, the high probabilities regarding people's estimates point to this bias. Furthermore, Moore and Schatz (2017) state that each form of overconfidence has different psychological origins, occurs under different conditions, creates different causes and different consequences, and therefore should not be evaluated in the same way. In this framework, some studies have reported that some personality traits increase overconfidence (e.g. Schaefer et al., 2004).

When the relationships between overconfidence and the decisions taken are examined, although Lambert, Bessiere and N'Goala (2012) state that overconfidence is independent of the difficulty of judgment, Benoit and Dubra (2011) state that easy decisions increase overconfidence. In addition, experience (Menkhoff et al., 2013; Broihanne et al., 2014), level of knowledge (Menkhoff et al., 2013; Mota et al., 2015; Aren and Canikli, 2018) and past achievements (Aren and Canikli, 2018) also strengthen overconfidence. Similarly, there is also a strong relationship between overconfidence levels and decisions of managers. Successful managers tend to make more agile and aggressive decisions since success increases overconfidence. They prefer high borrowing rates even if they may cause financial difficulties (Fairchild, 2005; Hackbarth, 2009). They do not have a specific choice in debt maturity. Some managers with overconfidence prefer long-term borrowing because they have optimistic views of the future and believe in growth opportunities (Ben-David et al., 2007; Malmendier et al., 2011; Seo et al., 2017). They are not bothered by high R\&D expenditures (Hirshleifer et al., 2012; Wang et al., 2018; Zavertiaeva et al., 2018; Hur et al., 2019) and they prefer low dividend distribution due to their belief in the growth potential of the business (Corderio, 2009; Deshmukh et al., 2009; Deshmukh et al., 2013). On the other hand, some managers with overconfidence, who believe that they will get their expected return in a short time, also prefer short-term borrowing (Chen and Chen, 2009; Landier and Thesmar, 2009; Huang et al., 2016) and they try to get a cost advantage with low inventory levels ( $\mathrm{Na}$ et al., 2020). Although it is seen that they sometimes get high returns (BerryStölzle et al., 2012; Kim et al., 2019), occasionally 
they have unprofitable merger and acquisition preferences (Malmendier and Tate, 2015) due to their overconfidence.

As a result, overconfidence is an important bias for managers and increases their risk taking (Lambert et al., 2012; Broihanne et al., 2014; Mota et al., 2015) as it causes them to react low to public information (Kahneman et al., 1998; Lambert et al., 2012; Mitroi and Stancu, 2014) and excessive to private information (Kahneman et al., 1998; Lambert et al., 2012).

\section{Status Quo}

Status quo is that the individual prefers the current situation without any reason, despite having different alternatives (Weathers et al., 2005; Masatlioglu and Ok, 2005; Ortoleva, 2010; Gal and Rucker, 2018). The current situation should be evaluated under two headings: The option that has already been tried and is still being tried, and the option assigned by someone else by default. This distinction is important for understanding the rationale of the status quo preference. In the case of a tried and continued trial, there is an option that has been tried for a while with the conscious or unconscious preference of the individual and whose positive and negative aspects are evaluated. But in the presence of the alternative assigned by default, there is not an option that is formed by the preference of the individual and has information about the positive and negative aspects. For this reason, Ritov and Baron (1992) emphasize that the dominant feeling in the presence of the tried option is the "desire to continue" (commission bias), but the dominant feeling in the presence of the recommended option as default is the "unwillingness of change" (omission bias). Anderson (2003) considers the second case as a delay in action.

When different alternatives are offered to a manager who evaluates the company's cash account with Treasury bonds for many years, it is within the scope of the first case to continue his/her past preference. In contrast, it is an example of the second case that a bank account is linked to an investment tool by default and the manager is informed that $\mathrm{s} /$ he can change it if s/he wishes. In the first case, the manager continues the preference made by his/herself or someone else in the past and is not uncomfortable with this preference because s/ he did not suffer any serious damage. The new alternative is an uncertain situation for the manager, and it harbors a sense of tension as the result of the new preference will always be compared to the past preference. Ritov and Baron (1992) state that although both behaviors are likely to equal gain and loss, individuals will choose inaction. The desire to continue existing is the most important obstacle in the development of processes in companies. The existing preference is safe, no responsibility is taken for its continuation, but there is the responsibility to change it. In the second case, knowledge and effort are required to change the default. It is safer and effortless to assume that the proposed option will be more suitable for him/her and his/her company. Something similar to this behavior is seen in lowcompetent managers who apply every suggestion coming from the board of directors without question. As in the previous case, low responsibility in this case also provides confidence for the manager.

Choosing the status quo may not always be erroneous. Sometimes the tried preference may be continued as it is the best available option. Nebel (2015) mentions three rational justifications of the status quo in this framework: replacement cost, uncertainty and cognitive limit. Even if there are more suitable choices than the current alternative, there may be costs to give up the current situation. The manager may not be very satisfied with his/ her employee. However, if the dismissal of the employee requires high compensation payment, the manager will continue with the existing personnel. Similarly, although the more modern machine is on the market, the purchase price of the new machine may require continuation with the old machine. Having information about the current situation gives a feeling of certainty regarding it. On the other hand, not having information about alternatives is a source of uncertainty for the manager. In this case, the aim is not to protect the status quo, but to avoid uncertainty. Sometimes there is information about alternatives but the manager is not competent to evaluate them. In this case, also, it is decided to continue the current alternative.

One of the two biggest variables that strengthen the status quo is the high number of alternatives, and the second is the difficulty of evaluating the alternatives, which is time consuming and require competence. Many researchers have pointed out that as the 
number of options increases (Redelmeier and Shafir, 1995; Kempf and Ruenzi, 2006) the decision problem becomes more difficult and complex (Greenleaf and Lehmann, 1995; Dhar, 1997; Luce, 1998; lyengar and Lepper, 2000; Dhar and Simonson, 2003; Dean, 2008; Gerasimou, 2016; Buturak and Evren, 2017), and the status quo protection behavior increases. In addition, past experiences (Li et al., 2009) and the fact that the same option has been made for a long time (Nebel, 2015) strengthen this bias. However, as experience (Loomes et al., 2009) and level of knowledge (Ryan and Bate, 2001; Nebel, 2015) increase, status quo weakens.

Status quo can be seen in all level organizations. While Thaler and Sunstein (2014) pointed to the presence of the status quo in public planning, Tangian (2004) mentioned the existence of the status quo in resource allocation in universities. Especially in a group - committee decisions, the effect gets stronger (Ruge-Murcia and Riboni, 2017). In addition, Woods, Gottschall, Matthews and Crasrud (2017) indicate that it is also seen in small business. Especially, it is one of the important obstacles to innovation (Bekir and Doss, 2020). In general, status quo helps managers to make quick decisions (Gärtne, 2018), reduces risk taking (Maner et al., 2007) and consequently, affects all decision processes (Dean et al., 2017). In this respect, it becomes possible for managers to be more connected to the status quo, especially as their age and seniority increase. Although from certain points it is considered inevitable, practices that will prevent managers from working in the same department, the same position and the same company for many years are required to protect firms from status quo dependence.

\section{Anchoring}

It is also referred to as a reference point or anchoring effect and reference point by some sources due to its adherence to a certain value. Anchoring is that individuals make decisions by adhering to a certain value without any foundation (Aren, 2019b). For the first time, Tversky and Kahneman (1974) pointed to this bias. In the relevant study of the authors, subjects were asked to turn the wheel of fortune numbered between 0 and 100 , and then the representation rate of African countries in the United Nations was asked. Looking at the answers, it was found that the ratio estimation of the subjects with a median of 10 in the wheel of fortune was 25 , while the ratio estimation of the subjects with a median of 45 was 65 . In addition, when they asked the results of the $1 \times 2 \times 3 \times 4 \times 5 \times 6 \times 7 \times 8$ and $8 \times 7 \times 6 \times 5 \times 4 \times 3 \times 2 \times 1$ operation to different subjects, they reported that the estimation median of the first operation was 512 , while the second operation was 2250 and explained this by anchoring the first few digits.

The human mind usually needs a reference point when making decisions (Schinckus, 2011). Managers pay attention to the amount of last year while estimating the sales figures for the next year. In salary increases, the inflation rate is the values that are accepted as the reference point of the salary hike of the person who receives the highest or the lowest wage. However, Furnham and Boo (2011) state that sometimes a mistake has been made in the use of a reference point and it may be the main reason for over or under-adjustment.

Individuals can accept various values and/or features that raise awareness in their decisions as reference points (Chapman and Johnson, 2000). This causes people who want to make decisions on similar topics to use different reference points and reach different judgments (Costa et al., 2017). These are the situations that are frequently encountered in internal company decisions. In evaluating the performance of staff, it is possible to create different judgments according to the evaluation criteria such as the change compared to the previous period performance, the difference according to the average performance of other employees in the relevant period, etc. Similarly, the figures presented by the CEO regarding his/her performance in the board of directors are mostly oriented to create a positive judgment using the reference point. There is no error in this process if the correct reference point is used and adjustments are made correctly. On the contrary, the correct reference point is very useful for making quick and comparable decisions. However, sometimes the first judgment protects its weight in the mind and adjustments made with new information remain insufficient (Mitroi and Stancu, 2014). New information is generally the information that can be accessed as opposed to all information (Tversky and Kahneman, 1974; Mota et al., 2015). This causes limited rationality and biased judgment. 
When the reference point is used many times in consecutive decision making processes and provides beneficial gains to the decision maker, it causes commitment (anchoring) in the decision maker. Similarly, Furnham and Boo (2011) indicate that the more the reference point confirms the decision-maker's information, the stronger the anchoring will be. However, Tversky and Kahneman (1974), in the first study on the bias, showed that the accuracy of the reference point or even whether it makes sense is not important for anchoring. In their well-known experiments, a passion flower was placed in front of the subjects, and they were asked to turn it and say the number that came in verbally. Then the representation rate of African countries in the United Nations was asked. The estimates of the subjects with higher numbers in the passionflower were higher than those of the lower numbers. Similar studies have continued in the following years, and it has been shown that after people say the last two digits of their ID numbers, even their estimates can affect the estimated value. These and similar studies show that people can be attached even to extremely unrelated values. Especially when lots of information comes not simultaneously but with long time differences, connecting to the first information becomes stronger (Arnold et al., 2018).

Managers are also not exempt from this bias. Especially in the next year's budget planning, the amount requested by the person or the department that applied for the application, or the highest or the lowest amount requested during that period, is the values that create affiliation. Also, elements of gaining market share, gaining competitive advantage, etc. are generally pushed to the second plan in project analysis and profit is anchored (Shapira and Shaver, 2014). Baker et al. (2018) also associate the high preference of suppliers' credits in working capital procurement with anchoring. Just as managers are affected by this bias, board members are also affected. Due to the anchoring thrown at some managers and their performances in the past, new managers always are compared by those anchoring people. In addition, as Xiao (2020) stated, the negative effect of anchoring is also seen in the merger and acquisition decisions.

Starck et al. (1997) examine the relationship between reference point - anchoring under two headings; the level of perception of information of the decision maker and the level of knowledge s/he has. The level of acceptability and plausibility is important for the perception of information. On the other hand, the level of knowledge of the person is evaluated in three categories: The existence of detailed knowledge of the decision maker on the subject, the presence of superficial knowledge and no knowledge. Smith et al. (2013) approach the subject in terms of cognitive abilities that can evaluate the information rather than the information that is owned and points out that low cognitive abilities can cause high anchoring. However, Englich and Soder (2009) state that expertise alone cannot be enough to get rid of anchoring bias. In addition, Furnham and Boo (2011) investigated its relationship with emotions and stated that sad mood may increase anchoring. McElroy and Dowd (2007) and Eroğlu and Croxton (2010) also found that various personality traits can increase anchoring.

\section{Hindsight}

Hindsight bias is the wrong beliefs of individuals that they have predicted that this result would come true after they had been informed about the event (Schkade and Kilboume, 1991; Guilbault et al., 2004). People sometimes adopt this kind of behavior in order to strengthen their self-confidence and sometimes to provide prestige in the eyes of others (Christensenszalanski and Willham, 1991; Guilbault et al., 2004; Roese and Vohs, 2012). Managers try to do their jobs in an environment where there is strong competition both internally and externally. They have to show superior performance and they should be able to convince their environment that they are performing this level of performance. For this, they feel the necessity to believe and say that they can foresee events. However, the future involves uncertainty. Uncertainty differs from risk and is unpredictable. In addition to this, managers have to make predictions about the future. Some of their predictions are successful, but some fail. However, people who have this bias claim that they know what will happen. As Aren (2019a) expressed, even if the result is predicted before that does not mean that this bias is not possessed. Because there are many predictable and unpredictable variables under uncertainty. However, the correct estimates can be also associated with luck, not with anticipation of the result. 
Roese and Vohs (2012) divide this bias into three sub-categories.

\section{Memory Distortion}

"I said it would happen", is the misremembering of the individual's previous judgment. The individual claims that $\mathrm{s} /$ he said the result in advance, but in fact s/he did not. Aren (2019a) states that this happens when the individual is asked to remember a past decision. Roese and Vohs (2012) also associate this with memory distortion. Memory distortion is more personal in terms of its characteristics and it helps to strengthen one's self-confidence.

\section{Inevitability}

"It had to happen", is the belief that the event that occurred has been predetermined. After the result has been achieved, the individual claims that there is no possibility of any other outcome than the actual result. In fact, many other results are possible. Guilbault et al. (2004) state that the person anchored the realized results. The main purpose of the individual is to avoid responsibility. Failure to see the inevitable rescues the person from responsibility and reduces the severity of blame.

\section{Foreseeability}

"I knew it would happen", is the belief in one's knowledge and ability. This is the wrong belief of an individual that s/he knows what will happen in advance. The difference from memory distortion is that here the individual does not even claim what $\mathrm{s} /$ he said in the past, but claims that s/he knows. It serves the purpose of raising the reputation of the person in his/her social and professional environment.

Hindsight is a bias that is frequently exposed with each category of its. Both managers and employees use this bias consciously or unconsciously, in order sometimes not to harm their self-confidence, sometimes to avoid harming their status, and sometimes to avoid responsibility. As also mentioned above, even if the results are said before, it does not mean that this bias will be exempt. For this reason, it is quite difficult to measure without performing experimental tests. The individual needs to know himself/herself well and evaluate objectively. In addition to this, most of the time, with the cut-in of defense mechanisms, it is possible for the person to act to change the internal and external reality.
Although Christensenszalanski and Willham (1991) and Munoz and Vicente (2018) express that this bias would decrease as the level of expertise increases. Guilbault et al. (2004) did not support this finding.

Another variable closely related to hindsight is narratives (Wilson and Gilbert, 2008). Unlike the story, narrative changes and diversifies according to the narrator. For this reason, all forms of hindsight have a narrative under it.Narratives allow rewriting history, as it includes a repeat presentation of the event for both narrator and listener. It also provides the results to be presented live or faint upon request and thus while sometimes serving memory distortion and foreseeability (with live presentations), sometimes helping inevitability with faint presentations. In this framework, it stands out as an application that managers frequently use in their professional lives. In addition to these, Biais and Weber (2009) associated hindsight with personality traits. Also, Guilbault et al. (2004) and Musch and Wagner (2007) stated that hindsight has a relationship with overconfidence, while Roese and Olson (2007) and Shepperd et al. (2008) have found evidence that it may be related to biases such as the illusion of control.

\section{Availability}

Availability bias is an estimate of the probability of occurrence of an event according to its ease of recall (Tversky and Kahneman, 1973; Tversky and Kahneman, 1974; Shams, 2002; Cohen, 2016; Kliger and Kudryavtsev, 2010; Javed et al., 2017; Chen et al., 2017; Kudryavtsev, 2018). People associate events that they can easily remember, imagine, or which occurred recently with a high probability of occurrence (Aren, 2019b). It is a bias that is also valid for managers. If the firm finds that several staff were corrupt over the past year, the manager develops a belief that corruption is common among employees. However, perhaps only three or four similar events may have occurred in the previous eight or ten-year period. But the events of the last year are considered more probable as they are easier to remember. Similarly, the fact that several customers delay or fail to pay their debts to the firm may create a perception in managers regarding the economic situation. Even if the number of such customers is a very small percentage of the total customers, it will be considered by the managers as a general economic problem rather than an individual 
Vol. 03(1-2) 08-23 (2021)

payment difficulty. When asked about the stock market performance of 2008 in investor confidence surveys in the USA in $2009,66 \%$ of respondents said that it fell. However, the stock market rose by $26.5 \%$ in 2008 (Cohen, 2016). The explanation of this wrong perception is considered as availability bias (Kliger and Kudryavtsev, 2010; Dimara et al., 2014).

Several variables affect availability bias. It is possible to evaluate those under two headings: Easy to remember and easy to be imagined. Many researchers have found that individuals see easyto-remember events as more possible and believe they occur more frequently (Tversky and Kahneman, 1973; Folkes, 1988; Shams, 2002; Keller et al., 2006; Kliger and Kudryavtsev, 2010; Dimara et al., 2014; Cohen, 2016; Meng, 2017; Kudryavtsev, 2018). In this context, the first and last events (Kliger and Kudryavtsev, 2010) and the ones that are easy to remember (Shams, 2002) increase the availability bias. For example, managers think that firms whose names they remember more easily are good firms that make higher purchases. They concentrate on the first or last information that comes to them compared to other information. They are in quest of approval for the initial information while they tend to attach importance to the final information. However, they do not make such an effort for the information they cannot easily remember and do not attach high importance to it. Dimara et al. (2014) accept the latest information as a recency effect. Easy imaginability, such as easy-to-remember events, also increases availability bias (Tversky and Kahneman, 1973; Kliger and Kudryavtsev, 2010; Dimara et al., 2014; Kudryavtsev, 2018). The easy of imaginability is closely related to the fact that the information is remembered, alive and emotional (Aren, 2019b). Managers are more likely to accept events whose results they can easily imagine. If the manager at the stage of launching a new product can easily imagine the sales of the product and its effects on the company, s/he will see these events more likely to happen.

The vibrant and exciting narration of events by others increases the availability by strengthening memorability and imaginability (Folkes, 1988; Kliger and Kudryavtsev, 2010; Chen et al., 2017; Kudryavtsev, 2018).In addition, its association with emotions increases availability in this framework
(Keller et al., 2006; Kliger and Kudryavtsev, 2010; Cohen, 2016; Kudryavtsev, 2018). The event or a lost or missed opportunity, which is described very vividly and impressively by a friend of the manager, creates ease of remembering in the listener and probability of recurrence is accepted as high. On the other hand, generally, events with positive emotions are easily remembered and their availability is considered high. For example, the fact that the manager takes a risk in a situation that is a turning point in business life and leads to the promotion of this situation creates high memorability regarding the positive aspects of risky situations.

Similarly, the effects of extraordinary events are also different (Agans and Shaffer, 1994). After the extraordinary event occurs, comprise of a relatively high expectation that it may happen again. Unusual disasters such as an earthquake or pandemic lead to the idea that these may happen again soon; however, the frequency of occurrence of these events is much longer. In addition to these, it is accepted that there is a relationship between experience and availability bias (Cohen, 2016; Meng, 2017). Managers may tend to attribute the possibilities they derive from their own experience rather than the actual possibilities for the events. For this reason, what they live and learn is more important than senior year. While the events are much more likely for a manager who has been exposed to limited events many times, the realization values of each event may be different for a manager who has different experiences.

\section{Discussion and Implications}

Decision making processes take place through the mutual interaction of some cognitive and psychological variables. Managers take many decisions within the framework of the activities of the companies. While some of these are less frequent decisions that are taken, such as a new product version, a new machine purchase, a new factory set-up, some others are decisions that may be taken every day such as the amount of order, responding to the discount request, etc. Over time, managers make these decisions under the influence of various biases and shortcuts. In this chapter, five basic biases that affect the decisions of managers are evaluated. 
Overconfidence is when a person sees his/her knowledge and abilities above his/her real level. It develops with personal successes and increases over time. Many successful managers appear to have overconfidence. Although overconfidence does not bring success, success increases overconfidence. It needs to be controlled because it increases risk taking. However, since managers have achieved their past success by taking risks, taking risk is not a danger to them. However, the point that they should pay attention to is whether the risk that they take is "risk of ruin". There are three forms of overconfidence: overestimation/ miscalibration, better than average/over placement, over precision. First, overestimation is one's over evaluation of his/her knowledge and skills. Secondly, better than average is when the person evaluates himself/herself better than the average, although s/ he does not consider himself/ herself very high level. The last one, over precision, is the unrealistic belief in the correctness of judgments. Regardless of its forms, awareness of this bias should be obtained as it may prevent managers from evaluating their knowledge and abilities realistically.

Status quo is defined as the continuation of the current situation without any reason, despite the existence of different available options. Although the status quo has rational reasons such as the invisible costs of changing the status quo, lacking the knowledge and the competence required to evaluate other alternatives, and not being able to predict the benefits and harms of any alternative due to the uncertainty in the markets, most of the time it is irrational. Managers also find it safe and effortless to repeat the practices they know about. The return of the tried alternative is more clearly known. However, this is not the case for the new alternative. For this reason, managers prefer the status quo to avoid risk. The biggest harm of this behavior to the company is that it prevents innovation.

Anchoring is a high commitment to particular knowledge or value without rational justification. Managers take several values as a reference to evaluate various alternatives. This is practical and useful. However, the value referred to creates binding effects and causes irrational judgments over time.
Hindsight effect is when people claim that, after the events have been concluded, they know and state that no other outcome would have been possible. This behavior, which is sometimes done not to damage self-esteem, and sometimes to strengthen the reputation, is one of the important obstacles to learning. Even if it has been said or known, if no action has been taken about it, there is no use in knowing it alone.

Finally, availability bias is a high weighting error according tothe ease of remembering events. It is easier to remember the recent developments, those with high emotional effects, striking ones, and events that have had a big impact on the firm or manager. But, this does not indicate that they occur very often and may still occur soon. In addition, managers exposed to this bias erroneously evaluate such unusual events to be higher than their real probability.

Managers are normal people with minds and emotions. In addition to many positive features, they can also have some biases. The important thing is to be aware of these biases and their impact on decisions. Evaluated generally, the relevant study provides important information for the recognition of the biases. However, it is not enough to know only the biases theoretically in making managerial decisions (Kahneman et al., 2011). One successful way to avoid the effects of biases is to get help from an external evaluator. The person is under the influence of System 1 while evaluating himself/ herself and his/her decisions (Kahneman et al., 2011). This is fast and automatic. For this reason, it does not give much opportunity to detect wrong decisions. However, someone else's evaluation of our decisions is usually done with system 2 (Kahneman et al., 2011) and by this means, the effect of biases can be purified. Kahneman et al. (2011) recommend a twelve-point guide to reduce the impact of biases in business decisions. For this, it is beneficial to have two people or groups, the decision maker and the evaluator. The evaluator should not ask a question to the person who made the first decision directly but should understand the decision maker's commitment to the decision. Managerial decisions in the context of questions such as "is the decision a joint decision of a single 
Vol. 03(1-2) 08-23 (2021)

person or a group, has different opinions been put forward, have the past success of the decision maker been effective in the decision making, have all alternatives been evaluated, would new information or information updates be requested if the same decision was taken again in the near future, may a halo effect have occurred, are decision makers tied to their past decisions, are they too optimistic, what is the worst-case scenario, and are the evaluators competent?" can reduce the impact of biases.

In this study, various biases that affect the decisionmaking processes of managers were evaluated from different aspects. These results provide important findings for both researchers and practitioners. Managers cannot be expected to make absolute rational decisions, they are normal people like everyone else. What is important is the development of enhanced emotional skills and the ability to make decisions with competence that the mind can take together. It was seen that raising awareness of these biases in terms of managers provides benefits such as realistic evaluation of themselves, giving more realistic weights to events when making decisions, reaching rational judgments more easily and being open to innovations. We think that the managers' consideration of these evaluations will contribute to their personal development. In addition, this study focused on only five of the biases in the literature. For this reason, in future studies, a wider framework can be drawn for managers by evaluating other biases in the literature.

\section{Acknowledgment}

This work received no financial support from any funding agency in the public, commercial, or nonprofit sectors.

\section{Funding}

The author(s) received no financial support for the research, authorship, and/or publication of this article.

\section{Conflict of Interest}

The authors do not have any conflict of interest with anyone.

\section{References}

1. Agans, R. P. \& Shaffer, L.S. (1994). "The Hindsight Bias: The Role of the Availability Heuristic and Perceived Risk". Basic and Applied Social Psychology, 15(4), 439-449. DOI: https://doi.org/10.1207/ s15324834basp1504_3

2. Akerlof, G. A. \& Shiller, R. J. (2009). Animal Spirits: How Human Psychology Drives the Economy, and Why It Matters for Global Capitalism. New Jersey, USA: Princeton University Press. (Hayvansal Güdüler İnsan Psikolojisi Ekonomiyi Nasıl Yönlendirir ve Küresel Kapitalizm İçin Niçin Önemlidir, Translated by Levent Konyar. İstanbul, Türkiye: Scala Yayıncılık. 2010).

3. Akerlof, G. A. \& Kranton R. E. (2010). Identity Economics: How Our Identities Shape Our Work, Wages, and Well-Being. Princeton, New Jersey: Princeton University Press. (Kimlik İktisadı: Kimliklerimiz, İşimizi, Ücretimizi ve Refahımızı Nasıl Şekillendiriyor?. Translated by Can Madenci. Ankara: Efil Yayınevi Yayınları. 2016.)

4. Anderson, C. J. (2003). "The psychology of doing nothing:Forms of decision avoidance result from reason and emotion". Psychological Bulletin, 129(1), 139-167. DOI: 10.1037//0033-2909.129.1.139

5. Aren, S. (2019a). "Evaluation of Psychological Biases in the Financial Framework". Journal of Social, Humanities and Administrative Sciences, 2(1), 1-25. DOI: 10.26677/ TR1010.2019.81

6. Aren, S. (2019b). "Theoretical Evaluation Of Psychological Biases In Behavioral Finance", The Journal of Business Economics and Management Research, 2(2), 127-160. DOI: 10.33416/baybem.559155

7. Aren, S. \& Canikli, S. (2018). "Typology of Behavioral Biases and Heuristics". 14TH International Strategic Management Conference July 12-14. Prague-Czechia, 557-562.

8. Arnold, M., Bassen, A. \& Frank, R. (2018). "Timing effects of corporate social responsibility disclosure: an experimental study with investment professionals". Journal of Sustainable Finance and Investment, 8(1), 
Vol. 03(1-2) 08-23 (2021)

45-71. DOI: 10.1080/20430795.2017.1368229

9. Baker, H. K., Kumar, S. \& Singh, H. P. (2018). "Behavioural biases among SME owners". International Journal of Management Practice, 11(3), 259-283. DOI: 10.1504/ IJMP.2018.092867

10. Bekir, I. \& Doss, F. (2020). "Status quo bias and attitude towards risk: An experimental investigation". Managerial and Decision Economics. (Early view), 1-12. DOI: https:// doi.org/10.1002/mde.3140

11. Ben-David, I., Graham, J. R. \& Harvey, C. R. (2007). "Managerial overconfidence and corporate policies". NBER Working Paper No. 13711. Chicago: The University of Chicago. DOI: $10.3386 / \mathrm{w} 13711$

12. Benoit, J.P. \& Dubra, J. (2011). "Apparent Overconfidence". Econometrica,79(5), 1591-1625. DOI: https://doi.org/10.3982/ ECTA8583

13. Berry-Stölzle, T. R., Eastman, E. M. \& Xu, J. (2018). "CEO Overconfidence and Earnings Management: Evidence from PropertyLiability Insurers' Loss Reserves". North American Actuarial Journal,22(3), 380-404. DOI: 10.1080/10920277.2017.1421977

14. Biais, B. \& Weber, M. (2009). "Hindsight Bias, Risk Perception, and Investment Performance" Management Science.55(6), 1018-1029. DOI: https://doi.org/10.1287/ mnsc. 1090.1000

15. Bratianu, C., Vatamanescu, E.M., Anagnoste, S.\& Dominici, G. (2020). "Untangling knowledge fields and knowledge dynamics within the decision-making process", Management Decision. 59(2),306-323. DOI: 10.1108/MD-05-2019-0559

16. Broihanne, M.H., Merli, M. \& Roger, P. (2014). "Overconfidence, Risk Perception and The Risk-Taking Behavior of Finance Professionals". Finance Research Letters,11(2), 64-73. DOI: 10.1016/j. frl.2013.11.002

17. Buturak, G. \& Evren, Ö. (2017). "Choice overload and asymmetric regret" Theoretical Economics. 12(3), 1029-1056. DOI: 10.3982/ TE2037

18. Chapman, G. B. \& Johnson, E. J. (2000). "Incorporating the irrelevant: Anchors in judgements of belief and value". Accessed July 4, 2018. http://www.communicationcache. com/uploads/1/0/8/8/10887248/ incorporating_-the_irrelevant-_anchors_in_ judgments_of_belief_and_value.pdf

19. Chen, S. \& Chen, L. (2009). "The Effect of Managerial Overconfidence on Listed Companies' Capital Structure and Debt Maturity Structure". International Conference on Management Science and Engineering $\left(16^{\text {th }}\right)$ September 14-16. Russia, Moscow. DOI: 10.1109/ICMSE.2009.5318042.

20. Chen, C., Cheng, J., Lin, F. \& Chihwei, P.(2017). "The Role of House Money Effect and Availability Heuristic in Investor Behavior". Management Decision, 55(8), 1598-1612. DOI: https://doi.org/10.1108/MD-10-20160725

21. Christensen-Szalanski, J.J.J. \& Willham, C. F. (1991). "The hindsight bias - a meta analysis". Organizational Behavior and Human Decision Processes, 48(1), 147-168. DOI: https://doi. org/10.1016/0749-5978(91)90010-Q

22. Chuang, W. \& Lee, B. (2006). "An Empirical Evaluation of The Overconfidence Hypothesis". Journal of Banking \& Finance,30(9), 2489-2515. DOI:https://doi. org/10.1016/j.jbankfin.2005.08.007

23. Cohen, D. (2016). "A Discussion on Behavioral Finance". Behavioral Finance. Vol:6. Accessed May, 2, 2021. https:// www.summitfinancial.com/wp/wpcontent/ uploads/2016/06/Behavioral_Finance_ part_6-Availability_Bias.pdf

24. Cordeiro, L. (2009). "Managerial Overconfidence and Dividend Policy". SSRN Electronic Journal, 1-36. DOI:10.2139/ ssrn. 1343805

25. Costa, D.F., Carvalho, F., Bruno, C.M. \& Prado, J.W.(2017). "Bibliometric Analysis on The Association Between Behavioral Finance and Decision Making With Cognitive Biases Such As Overconfidence, Anchoring Effect and Confirmation Bias". Scientometrics, 111(3), 1775-1799.

26. Cristofaro, M. (2017a). "Reducing Biases of Decision-Making Processes in Complex Organizations". Management Research Review, 40(3), 270-291.

27. Cristofaro, M. (2017b). "Herbert Simon's Bounded Rationality: its Evolution in Management and Cross feritilizing Contribution". Journal of Management 

Vol. 03(1-2) 08-23 (2021)

History, 23(2), 170-190.

28. Czerwonka, M. (2017). "Anchoring and Overconfidence:The Influence of Culture and Cognitive Abilities". International Journal of Management and Economics,53(3), 48-66. DOI: https://doi.org/10.1515/ijme-2017-0018

29. Daniel K., Hirshleifer, D. \& Subrahmanyam, A. (1998). Investor Psychology and Security Market Under-and Overreactions. The Journal of Finance, 53(6), 1839-1885 DOI: 10.1111/0022-1082.00077

30. Dean, M. (2008). "Status quo bias in large and small choice sets" Job Market Paper. Accessed November 19, 2018. http://www. columbia.edu/ md3405/Working_Paper_4. pdf

31. Dean, M., Kibris O. \& Masatlioglu, Y. (2017). "Limited attention and status quo bias". Journal of Economic Theory, 169(May), 93-127.

32. Deshmukh, S. G., Anand M. \& Howe, K. M. (2013). "CEO Overconfidence and dividend policy". Journal of Financial Intermediation, 22(3), 440-463. DOI: https://doi.org/10.1016/j. jfi.2013.02.003

33. Dhar, R. (1997). "Consumer preference for a no-choice option". Journal of Consumer Research, 24(2), 215-231. DOI: 10.1086/209506

34. Dhar, R. \& Simonson, I. (2003). "The effect of forced choice on choice". Journal of Marketing Research, 40(2), 146-160. DOI: https://www.jstor.org/stable/30038845

35. Dimara, E., Dragicevic, P. and Bezerianos, A. (2014). "Accounting for Availability Biases in Information Visualization". DECISIVe:Workshop on Dealing with Cognitive Biases in Visualisations. IEEE VIS2014, Nov 9th 2014, Paris, 1-3.

36. Englich, B.\& Soder, K. (2009). "Moody Experts-How Mood and Expertise Influence Judgmental Anchoring". Judgment and Decision Making,4(1), 41-50.

37. Eroglu, C.\& Croxton, K. L. (2010). "Biases in Judgmental Adjustments of Statistical Forecasts:The Role of Individual Differences". International Journal of Forecasting, 26(1), 116-133.

38. Fairchild, R. (2005). "Managerial overconfidence, moral hazard, and financing and investment decisions", Working paper
(March 27, 2009), Bath, UK: University of Bath.

39. Fellner, G. \& Kruegel, S. (2012). "Judgmental Overconfidence: Three Measures, One Bias?”. Journal of Economic Psychology,33(1), 142-154. DOI: https://doi.org/10.1016/j. joep.2011.07.008

40. Folkes, V. S. (1988). "The Availability Heuristic and Perceived Risk". Journal of Consumer Research, 15(1), 13-23. DOI: https://www. jstor.org/stable/2489168

41. Furnham, A. \& Boo, H.C. (2011). "A Literature Review of The Anchoring Effect". The Journal of Socio-Economics, 40(1), 35-42. DOI:10.1016/j.socec.2010.10.008

42. Gal, D. \& Rucker, D. D. (2018). "The loss of loss aversion: Will it loom larger than its gain?". Journal of Consumer Psychology, 28(3), 497-517. DOI: 10.1002/jcpy.1047

43. Gärtner, M. (2018). "The prosociality of intuitive decisions depends on the status quo". Journal of Behavioral and Experimental Economics, No. 74(June): 127-138. DOI: 10.1016/j.socec.2018.04.005

44. Gerasimou, G. (2016). "Asymmetric dominance, deferral, and status quo bias in a behavioral model of choice". Theory and Decision, 80(2), 295-312.

45. Greenleaf, E. A. \& Lehmann, D. R. (1995). "Reasons for substantial delay in consumer decision making". Journal of Consumer Research, 22(2), 186-199. DOI: https://doi. org/10.1086/209444

46. Guilbault, R. L., Bryant, F.B., Brockway, J. H. \& Posavac, E. J. (2004). "A meta-analysis of research on hindsight bias". Basic and Applied Social Psychology, 26(2-3), 103117.DOI: https://doi.org/10.1080/01973533. 2004.9646399

47. Hackbarth, D. (2009). "Determinants of corporate borrowing: a behavioral perspective". Journal of Corporate Finance, 15(4), 389-411. DOI: https://doi.org/10.1016/j. jcorpfin.2009.02.001

48. Harvard Law School Forum on Corporate Governance. Accessed May 5, 2020. https:// corpgov.law.harvard.edu/2018/02/12/ceotenure-rates/

49. Hirshleifer, D., Low, A. \& Teoh, S.H. (2012). "Are Overconfident CEOs Better Innovators?". The Journal of Finance,67(4), 1457-1498. 
Vol. 03(1-2) 08-23 (2021)

DOI: 10.1111/j.1540-6261.2012.01753.x

50. Huang, R., Tan, K. J. \& Faff, R. W. (2016). "CEO overconfidence and corporate debt maturity", Journal of Cooparate Finance, 36 (February), 93-110. DOI: https://doi. org/10.1016/j.jcorpfin.2015.10.009

51. Hur, K.S., Kim, D.H. \& Cheung, J.H. (2019). "Managerial Overconfidence and Cost Behavior of R\&D Expenditures". Sustainability, 11(18), 1-13. DOI:10.3390/ su11184878

52. lyengar, S. S. \& Lepper, M. (2000). "When choice is demotivating: Can one desire too much of a good thing?". Journal of Personality and Social Psychology, 79(6), 995-1006. DOI:10.1037/0022-3514.79.6.995

53. Javed, H., Bagh, T. \& Razzaq, S. (2017). "Herding Effects, Overconfidence, Availability Bias and Representativeness as Behavioral Determinants of Perceived Investment Performance: An Empirical Evidence from Pakistan Stock Exchange (PSX)". Journal of Global Economics, 5(4), 1-13.

54. Johnson, D. D.P. \& Fowler, J. H. (2011). "The Evolution of Overconfidence". Nature, 477, 317-320. DOI:10.1038/nature10384

55. Kahneman, D. \& Tversky, A. (1979). "Prospect Theory: An Analysis of Decision under Risk", Econometrica. 47(2), 263-291.

56. Kahneman, D., Lovallo, D. \& Sibony, O. (2011). "Before you make that big decision", Harvard Business Review,89(6), 50-60.

57. Keller, C. Siegrist, M. \& Gutscher, H. (2006). "The Role of the Affect and Availability Heuristics in Risk Communication". Risk Analysis, 26(3), 631-639. DOI: 10.1111/j.1539-6924.2006.00773.x

58. Kempf, A. \& Ruenzi, S. (2006). "Status quo bias and the number of alternatives:An empirical illustration from the mutual fund industry". Journal of Behavioral Finance, 7(4), 204-213.

59. Kim, H.A., Choi, S.U. \& Choi, W. (2019). "Managerial overconfidence and firm profitability". Asia-Pacific Journal of Accounting and Economics, (Early view), 1-25. DOI:10.1080/16081625.2019.1673190

60. Kliger, D.\& Kudryavtsev, A. (2010). "The Availability Heuristic and Investors' Reaction to Company-Specific Events". Journal of Behavioral Finance, 1(1), 50-65.
DOI:10.1080/15427561003591116

61. Kudryavtsev, A. (2018). "The Availability Heuristic and Reversals Following Large Stock Price Changes". Journal of Behavioral Finance,19(2), 159-176. DOI: https://doi.org /10.1080/15427560.2017.1374276

62. Landier, A.\& Thesmar, D. (2009). "Financial contracting with optimistic entrepreneurs", Review of Financial Studies, 22(1), 117-150. DOI: https://doi.org/10.1093/rfs/hhn065

63. Lambert, J., Bessiere, V. \& N'Goala, G. (2012). "Does Expertise Influence The Impact of Overconfidence on Judgment, Valuation And Investment Decision?". Journal of Economic Psychology, 33(6), 1115-1128. DOI: https:// doi.org/10.1016/j.joep.2012.07.007

64. Li, J., Ren, G. \& Liu, L. (2009). "An experimental study on investors' status quo bias". 2009 International Conference on Management Science \& Engineering $\left(16^{\text {th }}\right)$ September 14-16, Moscow: Russia.

65. Loomes, G. Orr, S. \& Sugden, R. (2009). "Taste uncertainty and status quo effects in consumer choice". Journal of Risk and Uncertainty, 39(2), 113-135.

66. Luce, M.F. (1998). "Choosing to avoid:Coping with negatively emotion-laden consumer decisions". Journal of Consumer Research, 24(4), 409-433. DOI: https://doi. org/10.1086/209518

67. Malmendier, U.\&Tate, G. (2015). "Behavioral CEOs: The Role of Managerial Overconfidence". Journal of Economic Perspectives,29(4), 37-60.

68. Malmendier, U., Tate, G. \& Yan, J. (2011). "Overconfidence and early-life experience: the effect of managerial traits on corporate financial policies", The Journal of Finance, 66(5), 1687-1733.

69. Maner, J.K., Gailliot, M.T., Butz, D. \& Peruche, M. (2007). "Power, risk, and the status quo: Does power promote riskier or more conservative decision making?" Personality and Social Psychology Bulletin, 33(4), 451-462. DOI:10.1177/0146167206297405

70. Masatlioglu, Y. \& Ok, E. A. (2005). "Rational choice with status quo bias". Journal of Economic Theory, 121(1), 1-29. DOI: https:// doi.org/10.1016/j.jet.2004.03.007

71. McElroy, T. \& Dowd, K. (2007). "Susceptibility to Anchoring Effects: How Openness To 

Vol. 03(1-2) 08-23 (2021)

Experience Influences Responses To Anchoring Cues". Judgment and Decision Making, 2(1), 48-53.

72. Meng, S. (2017). "Availability Heuristic Will Affect Decision-Making and Result in Bias". $3^{\text {rd }}$ International Conference on Management Science and Innovative Education Oct 14-15, Jinan, China, 267-272.

73. Menkhoff, L., Schmeling, M. \& Schmidt, U. (2013). "Overconfidence, Experience, and Professionalism: An Experimental Study". Journal of Economic Behavior and Organization, 86, 92-101.

74. Michailova, J., Maciulis, A. \& Tvaronaviciene, M. (2017). "Overconfidence, Risk Aversion and Individual Financial Decisions In Experimental Asset Markets". Economic Research-Ekonomska Istrazivanja,30(1), 1119-1131. DOI: https://doi.org/10.1080/13 31677X.2017.1311234

75. Mitroi, A.\& Stancu, I. (2014). "Biases, Anomalies, Psychology of A Loss and Individual Investment Decision Making". Economic Computation and Economic Cybernetics Studies and Research/Academy Of Economic Studies,48(1), 5-21.

76. Moore, D. A. \& Schatz, D. (2017). "The Three Faces of Overconfidence". Social and Personality Psychology Compass,11(8), 1-12. (Article Number: e12331). DOI: https:// doi.org/10.1111/spc3.12331

77. Mota, J. H., Moreira, A. C. \& Cossa, A. (2015). "Behavioural Factors in The Financial Decisions of Young Mozambicans". South African Journal of Business Management, 46(4), 11-22.

78. Muñoz, F. \& Vicente, R. (2018). "Hindsight effect: What are the actual cash flow timing skills of mutual fund investors?". Journal of Empirical Finance, 45, 181-193.

79. Musch, J. \& Wagner, T. (2007). “Did everybody know it all along? A review of individual differences in hindsight bias". Social Cognition, 25(1), 64-82.

80. Na, J., Kim, B. \& Sim, J. (2021). "COO's overconfidence and the firm's inventory performance". Production Planning and Control, 32(1), 19-33. DOI:10.1080/095372 87.2019.1711459

81. Nebel, J. M. (2015). "Status quo bias, rationality, and conservatism about value".
Ethics, 125(2), 449-476

82. Ortoleva, P. (2010). "Status quo bias, multiple priors and uncertainty aversion". Games and Economic Behavior, 69(2), 411-424. DOI: https://doi.org/10.1016/j.geb.2009.11.007

83. Peon, D., Antelo, M. \& Calvo, A. (2016). "Overconfidence and Risk Seeking in Credit Markets:An Experimental Game". Review of Managerial Science,10(3), 511-552.

84. Redelmeier, D. A. \& Shafir, E. (1995). "Medical decision making in situations that offer multiple alternative". Journal of the American Medical Association, 273(4), 302-305.

85. Ritov, I. \& Baron, J. (1992). "Status-quo and omission biases" Journal of Risk and Uncertainty, 5(1), 49-61.

86. Roese, N. J. \& Vohs, K. D. (2012). "Hindsight bias". Perspectives on Psychological Science, 7(5), 411-426.

87. Roese, N. J. \& Olson, J. M. (2007). "Better, Stronger, Faster Self-Serving Judgment, Affect Regulation, and the Optimal Vigilance Hypothesis". Perspectives on Psychological Science, 2, 124-141. DOI: 10.1111/j.17456916.2007.00033.x

88. Rose, S. (2005). The Future of The Brain The Promise and Perils of Tomorrow's Neuroscience. New York, USA: Oxford University Press. (21. Yüzyılda Beyin, Translated by Levent Can Yılmaz. İstanbul, Türkiye: Evrensel Basım Yayın)

89. Ruge-Murcia, F.\& Riboni, A. (2017). "Collective versus individual Decision-Making: A case study of the Bank of Israel Law". European Economic Review, 93 (April), 73-89.

90. Ryan, M.\& Bate, A. (2001). "Testing the assumptions of rationality, continuity and symmetry when applying discrete choice experiments in health care". Applied Economics Letters, 8(1), 59-63.

91. Schaefer, P. S., Williams, C.C., Goodie, A.S. \& Campbell, W. K. (2004). "Overconfidence and The Big Five". Journal of Research in Personality, 38(5), 473-480.

92. Schinckus, C. (2011). "Archeology of Behavioral Finance". The IUP Journal of Behavioral Finance,8(2), 7-22.

93. Schkade, D. A. \& Kilboume, L. M. (1991). "Expectation-outcome consistency and hindsight bias". Organizational Behavior and Human Decision Processes, 49(1), 105-123. 

Vol. 03(1-2) 08-23 (2021)

94. Seo, K., Kim, E.E.K. \& Sharma, A. (2017). "Examining the determinants of longterm debt in the US restaurant industry". International Journal of Contemporary Hospitality Management, 29(5), 1501-1520. DOI:10.1108/ijchm-06-2015-0274

95. Shams, M. A. (2002). "The Availability Heuristic in Judgments of Research Findings: Manipulations of Subjective Experience". The Osprey Journal of Ideas and Inquiry, All Volumes (2001-2008), 114-127.

96. Shapira, Z. \& Shaver, M. (2014). "Confounding changes in averages with marginal effects: how anchoring can destroy economic value in strategic investment assessments". Strategic Management Journal, 35(10), 1414-1426. DOI: https://doi.org/10.1002/smj.2165

97. Shepperd, J., Malone, W. \& Sweeny, K. (2008). "Exploring causes of the self-serving bias". Social and Personality Psychology Compass, 2(2), 895-908. DOI: https://doi. org/10.1111/j.1751-9004.2008.00078.x

98. Simon, H. A. (1972). "Theories of Bounded Rationality". Decision and Organization, edited by: C. B. McGuire and R. Radner, 161-176. Amsterdam: North-Holland.

99. Smith, A.R., Windschitl, P. D. \& Bruchmann, K. (2013). "Knowledge Matters: Anchoring Effects Are Moderated By Knowledge Level". European Journal of Social Psychology, 43(1), 97-108. DOI: https://doi.org/10.1002/ ejsp.1921

100. Strack, F. \& Mussweiler, T. (1997). "Explaining the Enigmatic Anchoring Effect: Mechanisms of Selective Accessibility". Journal of Personality and Social Psychology, 73(3), 437-446. DOI: https://doi.org/10.1037/00223514.73.3.437

101. Svenson, O. (1981). "Are We All Less Risky and More Skillful Than Our Fellow Drivers?". Acta Psychologica, 47(2), 143148. DOI: https://doi.org/10.1016/0001-6918 (81)90005-6

102. Tangian, A. (2004). "Redistribution of university budgets with respect to the status quo". European Journal of Operational Research, 157(2), 409-428.

103. Thaller R. H., Sunstein, C. R. (2008). Nudge, Yale University Press, New Haven London, (Translated, Enver Günsel, Pegasus Yayınları
2013, Ístanbul)

104. Todd, S. (2019). "Why CEO turnover in 2019 is so damn high". Accessed May 8, 2020. https://qz.com/work/1727662/why-ceoturnover-in-2019-is-at-a-record-high/

105. Tversky, A.\& Kahneman, D. (1974). "Judgment under uncertainty: Heuristics and biases". Science, 185(4157), 1124-1131. DOI: 10.1126/science.185.4157.1124

106. Tversky, A. \& Kahneman, D. (1973). "Availability: A Heuristic for Judging Frequency and Probability". Cognitive Psychology, 5(2), 207-232.

107. Wang, D., Sutherland, D., Ning, L., Wang, Y. \& Pan, X. (2018). "Exploring the influence of political connections and managerial overconfidence on R\&D intensity in China's large-scale private sector firms". Technovation, 69(January), 40-53. DOI:10.1016/j.technovation.2017.10.007

108. Weathers, D., Sharma, S. \& Niedrich, R. W. (2005). "The impact of the number of scale points, dispositional factors, and the status quo decision heuristic on scale reliability and response accuracy". Journal of Business Research, 58(11), 1516- 1524. DOI: https:// doi.org/10.1016/j.jbusres.2004.08.002

109. Wilson, T.D. \& Gilbert, D.T. (2008). "Explaining away: A model of affective adaptation". Perspectives on Psychological Science, 3(5), 370-386.

110. Woods, J. A., Gottschall, R., Matthews, C. H. \& Crasrud, A. L. (2017). "The influence of industry association involvement on technology desicion-making in small businesses". Journal of Enterprising Culture, 25(3), 317-337. DOI: https://doi.org/10.1142/ S0218495817500121

111. Xiao, H. (2020). "Anchoring in international merger and acquisition equity decisions: evidence from Chinese firms". Baltic Journal of Management, 15(3), 395-410. DOI: https:// doi.org/10.1108/BJM-04-2019-0124

112. Zavertiaeva, M.A., López-Iturriaga, F.J. \& Kuminova, E.V. (2018). "Better innovators or more innovators? Managerial overconfidence and corporate R\&D". Managerial and Decision Economics, 39(4), 447-461. DOI:10.1002/ mde.2917 